\title{
Pertumbuhan Perusahaan, Kebijakan Dividen, Leverage, Profitabilitas Dan Nilai Perusahaan Manufaktur Indonesia
}

\author{
Amira, Myrna Sofia \\ Universitas Maritim Raja Ali Haji, Tanjungpinang, Kepulauan Riau 29100, Indonesia
}

\begin{abstract}
ABSTRAK : Pengaruh pertumbuhan perusahaan, kebijakan dividen, leverage dan profitabilitas terhadap nilai perusahaan. Penelitian ini bertujuan untuk mengetahui pengaruh pertumbuhan perusahaan, kebijakan dividen, leverage dan profitabilitas terhadap nilai perusahaan pada perusahaan manufaktur yang terdaftar di bursa efek indonesia (bei) pada tahun 2014-2017. Metode penelitian asosiatif dengan menggunakan pendekatan kuantitatif yaitu penelitian yang kemudian diolah dan dianalisis untuk diambil kesimpulan.Penelitian ini menunjukkan bahwa pertumbuhan perusahaan berpengaruh positif dan signifikan terhadap nilai perusahaan.Kebijakan dividen berpengaruh positif dan signifikan terhadap nilai perusahaan. Leverage tidak berpengaruh signifikan terhadap nilai perusahaan. Profitabilitas berpengaruh positif dan signifikan terhadap nilai peusahaan.
\end{abstract}

Kata kunci:Pertumbuhan Perusahaan; Kebijakan Dividen; Leverage;Profitabilitas; Nilai Perusahaan

\begin{abstract}
The Effect of company growth, dividend policy, leverage and profitability on firm value. This study aims to determine the effect of company growth, dividend policy, leverage and profitability on firm value in manufacturing companies listed on the Indonesian stock exchange (BEI) in 2014-2017. Associative research methods using a quantitative approach that is research which is then processed and analyzed for conclusions. This study shows that company growth has a positive and significant effect on firm value. Dividend policy has a positive and significant effect on firm value. Leverage does not have a significant effect on firm value. Profitability has a positive and significant effect on the value of the company.
\end{abstract}

Keywords:Company Growth; Dividen Policy; Leverage; Profitability; Firm Value

Email Address : amira1@gmail.com

\section{Pendahuluan}

Pada era globalisasi saat ini, membuat setiap perusahaan manufaktur harus mampu bersaing dengan perusahaan lainnya.Persaingan tersebut membuat perusahaan semakin meningkatkan kinerjannya agar tujuan perusahaan dapat tercapai.Setiap perusahaan juga harus mampu memberikan sinyal positif kepada calon investor atau para pemegang saham tentang nilai perusahaannya bahwa perusahaan mereka tepat sebagai alternatif investasi. Dengan banyaknya jumlah perusahaan manufaktur yang terdaftar di Bursa Efek Indonesia (BEI), tentunya akan membuat investor harus mengambil keputusan untuk berinvestasi. Karena apabila keputusan investasi tersebut kurang tepat, kemungkinan yang akan terjadi adalah investor tidak akan memperoleh return saham karena perusahaan mengalami kerugian atau kebangkrutan. Oleh karena itu, sebaiknya 
setiap investor hendaknya mengumpulkan informasi yang akan ditetapkan untuk berinvestasi.

Nilai perusahaan merupakan harga saham yang bersedia dibayar oleh investor untuk suatu perusahaan. Nilai suatu perusahaan dapat diukur dari nilai saham dipasar dengan membandingkan nilai buku perlembar saham.Namun, permasalahan yang terjadi pada perusahaan Manufaktur adalah nilai PBV yang cenderung tidak stabil setiap tahunnya, terkadang mengalami kenaikan maupun penurunan.Nilai perusahaan ditentukan dari harga saham di pasar. Jika harga saham tinggi maka nilai perusahaan juga akan tinggi. Nilai perusahaan yang tinggi akan menarik investor karena perusahaan di nilai mempunyai kinerja dan prospek perusahaan di masa depan. PBV yang tinggi mencerminkan harga saham yang tinggi dibandingkan nilai buku perlembar saham.Semakin tinggi harga saham, semakin berhasil perusahaan menciptakan nilai bagi pemegang saham. Keberhasilan perusahaan menciptakan nilai tersebut tentunya memberikan harapan kepada pemegang saham berupa return yang besar. Namun sebaliknya jika nilai PBV nya rendah maka return yang diperoleh investor juga rendah.

Ada beberapa faktor yang dapat memengaruhi meningkatnya nilai perusahaan seperti pertumbuhan perusahaan menggambarkan kemampuan perusahaan meningkatkan aset perusahaan.Penelitian Chusnitah dan Retnani (2017) dan Putri (2015) menunjukkan bahwa pertumbuhan perusahaan (growth) berpengaruh signifikan terhadap nilai perusahaan.Hal ini sangat berbeda dengan penelitian yang dilakukan Wibawa (2013) menyatakan bahwa pertumbuhan perusahaan tidak berpengaruh signifikan terhadap nilai perusahaan.

Kebijakan dividen dalam perusahaan menggambarkan kemampuan perusahaan dalam membagikan laba yang diperoleh kepada para pemegang saham atau investor. Hasil penelitian yang dilakukan Sudiartha (2016), Ngurah, Adi, dan Lestari (2016) menunjukkan bahwa kebijakan dividen memiliki pengaruh yang signifikan dengan nilai perusahaan. Penelitian tersebut berbeda dengan Mardiyati (2012) menyatakan bahwa kebijakan dividen memiliki pengaruh yang tidak signifikan terhadap nilai perusahaan.

Leverage menggambarkan mengenai tingkat risiko perusahaan dalam memenuhi seluruh kewajibannya dengan menggunakan modal sendiri. Hasil penelitian yang dilakukan Rudangga, I Gusti Ngurah Gede; Sudiarta (2016), Ernawati dan Widyawati (2015), Mindra, Sukma dan Erawati (2014), Kuzey, Ali, dan Delen (2014) menunjukkan bahwa variabel leverage berpengaruh signifikan terhadap nilai perusahaan. Hasil penelitian ini berbeda Prasetyorini (2013) dan Putu Mikhy Novari (2016) menyatakan bahwa leverage memiliki pengaruh yang tidak signifikan terhadap nilai perusahaan.

Profitabilitas menggambarkan kemampuan perusahaan dalam menghasilkan laba dalam satu periode tertentu. Penelitian yang dilakukan Purnama (2016), Kuzey, Ali, dan Delen (2014), Dewi, Ayu Sri Mahatma; Wirajaya (2013) dan Widiastari, Putu Ayu; Yasa (2018) menunjukkan bahwa profitabilitas berpengaruh signifikan terhadap nilai perusahaan. Hasil penelitian ini bertentangan dengan penelitian yang dilakukan M. T. Putri (2017) menyatakan bahwa profitabilitas tidak berpengaruh terhadap nilai perusahaan.disediakan untuk membantu penulis dalam memformat naskah yang akan dikirim ke Jurnal Bahtera inovasi (Pengutipan: Mendeley). Penulis dapat menyalin-menempel tulisannya di template ini.Untuk menyalin-menempel teks dari sumber, diharapkan untuk menggunakan fasilitas 'Paste Special' pada Microsoft Word dan pilih 'Unformatted Text' untuk mempertahankan format teks dan paragraf pada template ini.

Bagian pendahuluan terutama berisi: (1) permasalahan penelitian; (2) rangkuman kajian teoritik yang berkaitan dengan masalah yang diteliti (3) wawasan dan rencana pemecahan masalah; (4) rumusan tujuan 
penelitian. Pada bagian ini kadang-kadang juga dimuat harapan akan hasil dan manfaat penelitian. Panjang bagian pendahuluan sekitar 2-3 halaman dan diketik dengan 1,15 spasi (atau mengikuti ketentuan penulisan jurnal ilmiah tempat artikel tersebut hendak diterbitkan).Template untuk format artikel ini dibuat dalam MS Word, dan selanjutnya disimpan dalam format doc atau docx. Batang tubuh teks menggunakan font: Times New Roman 11, regular, spasi 1.15, spacing before 0 pt, after $0 \mathrm{pt}$ ).

\section{Metode Penelitian}

\section{Objek dan Ruang Lingkup Penelitian}

Untuk mengetahui pengaruh pertumbuhan perusahaan, kebijakan dividen, leverage, dan profitabilitas terhadap nilai perusahaan pada perusahaan manufaktur yang terdaftar di Bursa Efek Indonesia periode 20142017, maka objek penelitian yang digunakan dalam penelitian ini adalah laporan keuangan di Bursa Efek Indonesia dan berkaitan langsung dengan perusahaan manufaktur yang berupa laporan keuangan (financial report) tahun 2014, 2015, 2016, dan 2017 yang dipublikasikan di Bursa Efek Indonesia.

\section{Populasi}

Menurut Sugiyono (2016:80) mendefinisikan populasi adalah wilayah generalisasi yang terdiri atas objek atau subjek yang mempunyai kuantitas dan karakteristik tertentu yang ditetapkan oleh peneliti untuk dipelajari dan kemudian ditarik kesimpulannya.Populasi pada penelitian ini adalah seluruh perusahaan manufaktur yang terdaftar di Bursa Efek Indonesia (BEI) selama periode tahun 2014-2017 berjumlah 133 perusahaan.

\section{Sampel}

Menurut Sugiyono (2016:81) sampel adalah bagian dari jumlah dan karakteristik yang dimiliki oleh populasi tersebut.Teknik pengambilan sampel yang digunakan dalam penelitian ini adalah teknik sampling (purposive
sampling).Menurut Narbuko, Cholid; Achmadi (2016:116) purposive sampling merupakan teknik yang berdasarkan pada ciriciri atau sifat-sifat tertentu yang diperkirakan mempunyai hubungan erat dengan ciri-ciri atau sifat-sifat yang ada dalam populasi yang sudah diketahui sebelumnya. Dengan kata lain, purposive sampling adalah teknik penentuan sampel dengan pertimbangan atau kriteria-kriteria tertentu. Adapun kriteria penentuan sampel yang digunakan dalam penelitian ini adalah sebagai berikut:

1. Perusahaan manufaktur yang terus terdaftar di Bursa Efek Indonesia periode 2014-2017.

2. Perusahaan yang mempublikasikan laporan keuangan secara terus menerus selama periode 2014-2017.

3. Perusahaan manufaktur yang laporan keuangan dinyatakan dalam mata uang Rupiah secara berturut-turut selama periode 2014-2017

4. Perusahaan yang manufaktur memperoleh laba secara terus menerus selama periode 2014-2017.

5. Perusahaan manufaktur yang secara terus menerus membagikan dividen selama periode 2014-2017.

6. Perusahaan manufaktur yangmengalami pertumbuhan aktiva yang positif periode 2014-2017.

\section{Prosedur Pengumpulan Data}

Metode pengumpulan data pada penelitian ini adalah metode dokumentasi dilakukan dengan cara mengumpulkan, mencatat, dan mempelajari data berupa laporan keuangan (finansial report) yang diperoleh dari web site Bursa Efek Indonesia (BEI) yaitu www.idx.co.id dan dari web site saham ok untuk Periode 2014-2017.

\section{Metode Analisis}

Penelitian ini menggunakan metode data kuantitatif sebagai metode analisis dengan menggunakan program SPSS sebagai alat untuk menguji data tersebut, dengan tujuan untuk mendapat informasi yang efektif yang terdapat dalam data dan hasilnya 
digunakan untuk memecahkan masalah.

\section{Uji Statistik Deskriptif}

Menurut Ghozali (2016:19), Statistik deskriptif memberikan gambaran atau deskripsi suatu data yang dilihat dari rata-rata (mean), standar deviasi, varian, maksimum dan minimum.

\section{Uji Asumsi Klasik}

Pengujian asumsi klasik dalam penelitian ini menggunakan model regresi linier berganda.

\section{Uji Normalitas}

Menurut Ghozali (2016:154) uji normalitas bertujuan untuk menguji apakah model regresi, variabel pengganggu atau residual memiliki distribusi normal.Data terdistribusi normal jika nilai signifikan lebih besar dari 0.05 .

\section{Uji Multikolinearitas}

Menurut Ghozali (2016:103) uji multikolinearitas bertujuan untuk menguji apakah model regresi ditemukan adanya korelasi diantara variabel bebas (independen).Deteksi adanya multikolinearitas dapat dilihat pada hasil collinearity statistic.Pada collinearity statistic tersebut terdapat nilai VIF (Variance Inflation Factor) dan tolerance.Jika nilai tolerance $>0.10$ dan VIF (Variance Inflation Factor) $<10$, maka dapat diartikan bahwa tidak terjadi multikolinieritas.

\section{Uji Autokorelasi}

Uji autokorelasi bertujuan menguji apakah dalam model regresi linear ada korelasi antara kesalahan pengganggu pada periode $t$ dengan kesalahan pengganggu pada periode t-1 (sebelumnya) (Ghozali, 2016:107). Salah satu ukuran dalam menentukan ada tidaknya masalah autokorelasi dengan uji Durbin-Watson (DW) jika nilai DW berada di antara -2 dan +2 atau -2 $\leq \mathrm{DW} \leq+2$.

\section{Uji Heteroskedastisitas}

Menurut Ghozali (2016:134) uji heteroskedastisitas bertujuan menguji apakah dalam model regresi terjadi ketidaksamaan variance dari residual satu pengamatan ke pengamatan lain. Jika variance dari residual satu pengamatan ke pengamatan lain tetap, maka disebut Homoskesdatisitas dan jika berbeda disebut Heteroskedastisitas. Model regresi yang baik adalah yang Homoskesdatisitas atau tidak terjadi Heteroskedastisitas. Ada beberapa metode pengujian yang digunakan yaitu uji grafik plot dengan melihat antara nilai prediksi variabel terikat (dependen) yaitu ZPRED dengan residualnya SRESID dan uji sperman's rho yaitu mengorelasi variabel independen dengan nilai unstandardized residual.

\section{Analisis Regresi Linier Berganda}

Analisis regresi linier berganda adalah hubungan secara linear variabel pertumbuhan perusahaan, kebijakan dividen, leverage dan profitabilitas dengan nilai perusahaan. Persamaan regresi linier berganda sebagai berikut: $\mathrm{Y}=\mathrm{a}+\mathrm{b} 1 \mathrm{x} 1+\mathrm{b} 2 \mathrm{x} 2+\mathrm{b} 3 \times 3+\mathrm{b} 4 \mathrm{x} 4$ $+\mathrm{e}$.

\section{Pengujian Hipotesis}

Menurut Priyatno (2014) Pengujian hipotesis adalah pengujian yang bertujuan untuk mengetahui apakah kesimpulan pada sampel dapat berlaku untuk populasi atau dapat digeneralisasi.

\section{Uji Koefisien Secara Parsial (Uji Statistik t)}

Uji ini digunakan untuk mengetahui apakah model regresi variabel pertumbuhan perusahaan, kebijakan dividen, leverage dan profitabilitas secara parsial berpengaruh signifikan terhadap nilai perusahaan. Tingkat Signifikan menggunakan $0.05(\mathrm{a}=5 \%)$.

\section{Uji Koefisien Secara Simultan (Uji Statistik F)}

Uji ini digunakan untuk mengetahui apakah model regresi variabel pertumbuhan perusahaan, kebijakan dividen, leverage dan profitabilitas secara bersama-sama atau simultan berpengaruh signifikan terhadap nilai perusahaan. Tingkat Signifikan menggunakan $0.05(\mathrm{a}=5 \%)$. 


\section{Uji Koefisien Determinasi (R2)}

Menurut Ghozali (2016:95) Koefisien determinasi (R2) digunakan untuk mengukur seberapa jauh kemampuan model dalam menerangkan variasi variabel dependen.

\section{Hasil dan Pembahasan}

Uji Statistik Deskriptif

Penelitian ini menggunakan empat variabel independen yaitu pertumbuhan perusahaan, kebijakan dividen, leverage dan profitabilitas dan variabel dependen yaitu nilai perusahaan. Hasil analisis statistik deskriptif dari variabel-variabel tersebut dapat dilihat pada tabel 1.

Tabel 1. Hasil Statistik Deskriptif Variabel Penelitian Sebelum Outlier

\begin{tabular}{|l|r|r|r|c|c|}
\hline & \multicolumn{1}{|c|}{$\mathrm{N}$} & Minimum & Maximum & \multicolumn{1}{c|}{ Mean } & $\begin{array}{c}\text { Std. } \\
\text { Deviation }\end{array}$ \\
\hline Nilai Perusahaan & 84 & .06421 & 22.29148 & 3.6460535 & 3.78317690 \\
Pertumbuhan & 84 & .00289 & .61041 & .1336480 & .11504533 \\
Perusahaan & 84 & .07480 & 2.08144 & .4473646 & .34888551 \\
Kebijakan Dividen & 84 & .03906 & 2.19441 & .6444450 & .47386842 \\
Levera ge & 84 & .01087 & .75426 & .1602410 & .11189219 \\
Profitabilitas & 84 & & & & \\
Valid N (listwise) & & & \\
\hline
\end{tabular}

(Sumber: Output SPSS Versi 24)

Karena data mengalami masalah tidak normal dalam uji normalitas, maka dilakukan outlier dengan nilai (ZScore). Hasil untuk analisis statistik deskriptif akan mengalami perubahan karena jumlah observasi menjadi berkurang, hal ini dapat dilihat pada tabel 2 berikut:

Tabel 2. Hasil Statistik Deskriptif Variabel Penelitian Setelah Outlier

\begin{tabular}{|l|r|r|r|c|c|}
\hline & \multicolumn{1}{|c|}{ N } & Minimum & Maximum & Mean & $\begin{array}{c}\text { Std. } \\
\text { Deviation }\end{array}$ \\
\hline Nilai Perusahaan & 75 & .06421 & 13.65840 & 3.4015572 & 2.93544613 \\
Pertumbuhan & 75 & .00289 & .42529 & .1198795 & .08205703 \\
Perusahaan & 75 & .07480 & 1.25440 & .4102809 & .25783322 \\
Kebijakan Dividen & 75 & .03906 & 1.99489 & .5967737 & .42567112 \\
Lever age & 75 & .01087 & .37683 & .1577659 & .08745351 \\
Profitabilitas & 75 & & & & \\
Valid N (listwise) & (Sumber: Output SPSS Versi 24) \\
(Sumb
\end{tabular}

Berdasarkan hasil penelitian pada tabel diatas dapat diketahui bahwa jumlah data adalah 84 data.Setelah di outlier menjadi 75 data, terdapat 9 data yang dihilangkan.

\section{Uji Normalitas}

Tabel 3. Hasil Uji Normalitas Sebelum Outlier

\begin{tabular}{|c|c|c|}
\hline & & $\begin{array}{l}\text { Unstandar dized } \\
\text { Residual }\end{array}$ \\
\hline $\mathrm{N}$ & & 84 \\
\hline \multirow[t]{2}{*}{ Normal Parameterg $\sigma^{2}, 0$} & Mean & .0000000 \\
\hline & Std. Deviation & 2.55109161 \\
\hline \multirow[t]{3}{*}{ Most Extreme Differences } & Absolute & .106 \\
\hline & Positive & .106 \\
\hline & Negative & -.094 \\
\hline Test Statistic & & .106 \\
\hline Asymp. Sig. (2-tailed) & & $.022^{\mathrm{c}}$ \\
\hline
\end{tabular}

Tabel 4. Hasil Uji Normalitas Setelah Outlier

\begin{tabular}{|ll|r|}
\hline & & \multicolumn{1}{|c|}{$\begin{array}{c}\text { Unstandardized } \\
\text { Residual }\end{array}$} \\
\hline N & Mean & 75 \\
& Std. Deviation & .0000000 \\
Most Extreme Differences & Absolute & 2.23799106 \\
& Positive & .101 \\
& Negative & .101 \\
& & -.093 \\
Test Statistic & & .101 \\
Asymp. Sig. (2-tailed) & $.056^{\circ}$ \\
\hline (Sumber: Output SP.SS Versi 24) &
\end{tabular}

Dari hasil uji statistik tabel 4.4, besarnya nilai Test Statistic adalah 0.106 dan signifikansinya $0.022<0.05$, maka Ho tidak dapat diterima, yang berarti data residual berdistribusi tidak normal.Agar data residual berdistribusi normal maka dilakukan outlier dengan nilai (ZScore).Dan dari hasil uji statistik tabel 4.5, besarnya nilai Test Statistic adalah 0.101 dan signifikansinya $0.056>$ 0.05, maka Ho dapat diterima, yang berarti data residual berdistribusi secara normal karena memiliki tingkat signifikan diatas 0.05.

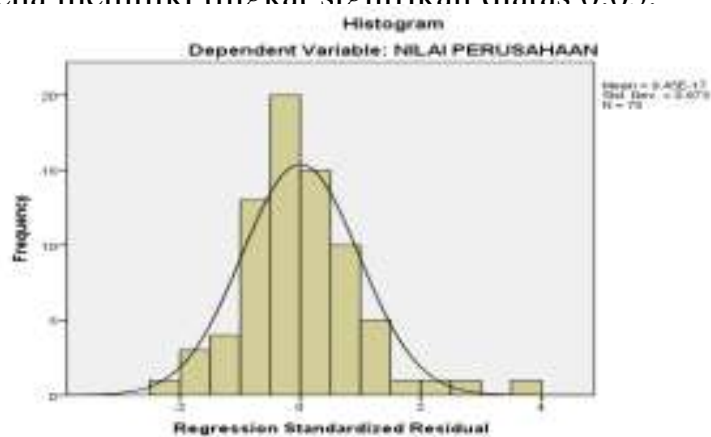

Gambar 1. Hasil Uji Normalitas Histogram (Sumber: Output SPSS Versi 24)

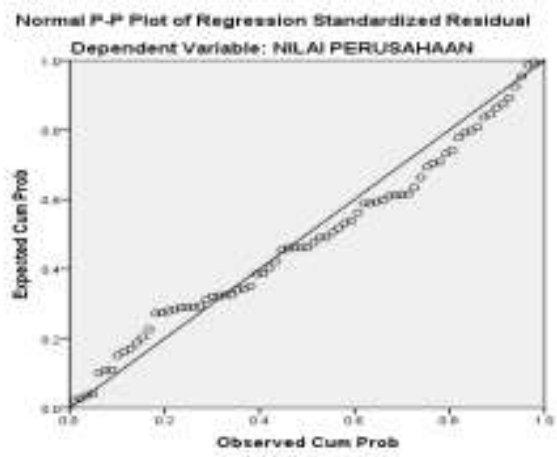


Uji Multikolonieritas

Tabel 5. Hasil Uji Multikolonieritas

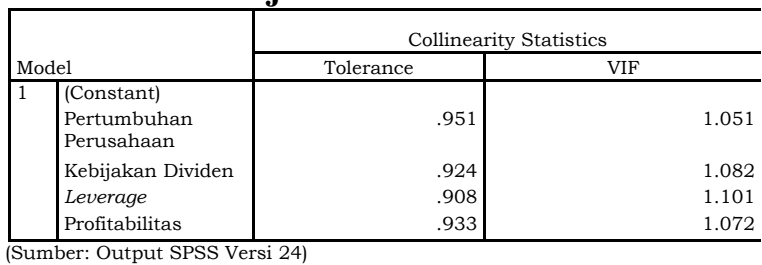

Berdasarkan tabel 5, maka dapat diketahui nilai VIF untuk variabel pertumbuhan perusahaan sebesar $1.051<10$ dan nilai tolerance $0.951>0.10$, Nilai VIF untuk variabel kebijakan dividen sebesar $1.082<10$ dan nilai tolerance $0.924>0.10$, Nilai VIF untuk variabel leverage sebesar $1.101<10$ dan nilai tolerance $0.908>0.10$ dan Nilai VIF untuk variabel profitabilitas sebesar $1.072<10$ dan nilai tolerance $0.933>0.10$ sehingga dapat disimpulkan bahwa tidak terjadi multikolonieritas antar variabel independen dalam model regresi.

\section{Uji Autokorelasi}

\section{Tabel 6. Hasil Uji Autokorelasi}

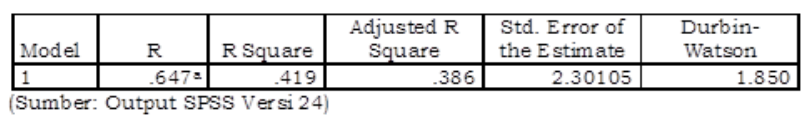

Dari tabel 6, dapat diketahui bahwa nilai Durbin-Watson sebesar 1.850 berada di antara -2 dan +2 atau nilai $1.850 \leq+2$. Sehingga dapat disimpulkan tidak terjadi gejala autokorelasi pada model regresi.

\section{Uji Heterokedastisitas}

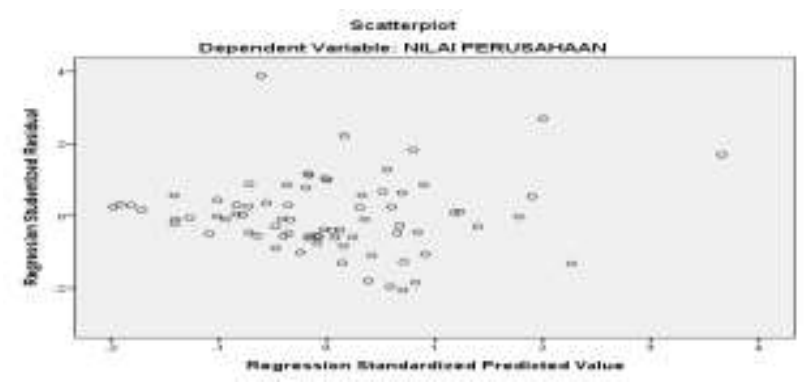

Gambar 3. Hasil Uji Heteroskedastisitas Scatterplot

(Sumber: Output SPSS Versi 24)

Dari gambar 3, dapat dilihat bahwa titiktitik yang berbentuk menyebar secara acak, tersebar baik diatas maupun dibawah angka 0 pada sumbu Y, hal ini dapat disimpulkan bahwa tidak terjadi heteroskedastisitas pada model regresi, sehingga model regresi layak digunakan.

Tabel 7. Hasil Uji

HeteroskedastisitasSperman's Rho

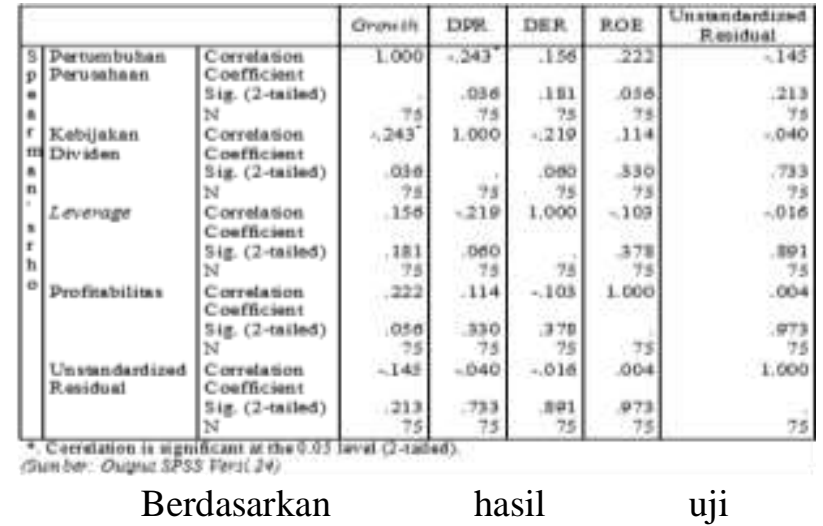

heteroskedastisitas pada tabel 7, diketahui bahwa nilai signifikansi masing-masing variabel independen di atas tingkat kepercayaan 5\% atau 0.05.Pertumbuhan perusahaan 0.213 , kebijakan dividen 0.733 , leverage 0.891 dan profitabilitas 0.973.Jadi dapat disimpulkan model regresi tidak mengandung adanya heteroskedastisitas.

Analisis Regresi Linear Berganda

Analisis regresi linear berganda digunakan untuk mengetahui pengaruh dari masing-masing variabel independen terhadap variabel dependen.Berikut hasil analisis regresi.

Tabel 8. Hasil Analisis Regresi Berganda

\begin{tabular}{|c|c|c|c|c|c|c|}
\hline & \multirow[t]{2}{*}{ Model } & \multicolumn{2}{|c|}{$\begin{array}{c}\text { Unstandardized } \\
\text { Coefficients }\end{array}$} & $\begin{array}{c}\text { Standardized } \\
\text { Coefficients }\end{array}$ & \multirow[t]{2}{*}{$\mathrm{T}$} & \multirow{2}{*}{ Sig. } \\
\hline & & B & $\begin{array}{l}\text { Std. } \\
\text { Error }\end{array}$ & Beta & & \\
\hline \multirow[t]{5}{*}{1} & (Constant) & -1.980 & .928 & & -2.133 & .036 \\
\hline & $\begin{array}{l}\text { Pertumbuhan } \\
\text { Perusahaan }\end{array}$ & 13.470 & 3.329 & .378 & 4.047 & .000 \\
\hline & $\begin{array}{l}\text { Kebijakan } \\
\text { Dividen }\end{array}$ & 2.555 & 1.078 & .225 & 2.371 & .020 \\
\hline & Leverage & .759 & .660 & .110 & 1.150 & .254 \\
\hline & Profitabilitas & 14.357 & 3.156 & .429 & 4.549 & .000 \\
\hline
\end{tabular}

Dari persamaan regresi, maka dapat ditulis persamaa regresi sebagai berikut: $\mathrm{Y}=$ $1.980+13.470 \mathrm{X} 1+2.555 \mathrm{X} 2+0.759 \mathrm{X} 3+$ $14.357 \mathrm{X} 4+\mathrm{e}$.

Pengujian Hipotesis

Uji Koefisien Secara Parsial (Uji t)

Tabel 9.Hasil Uji Koefisien Regresi Parsial (Uji t) 


\begin{tabular}{|c|c|c|c|c|c|c|}
\hline & \multirow[t]{2}{*}{ Model } & \multicolumn{2}{|c|}{$\begin{array}{l}\text { Unstandardized } \\
\text { Coefficients }\end{array}$} & $\begin{array}{c}\text { Standardized } \\
\text { Coefficients }\end{array}$ & \multirow[t]{2}{*}{$\mathrm{T}$} & \multirow{2}{*}{ Sig. } \\
\hline & & B & $\begin{array}{l}\text { Std. } \\
\text { Error }\end{array}$ & Beta & & \\
\hline \multirow[t]{5}{*}{1} & (Constant) & -1.980 & .928 & & -2.133 & .036 \\
\hline & $\begin{array}{l}\text { Pertumbuhan } \\
\text { Perusahaan }\end{array}$ & 13.470 & 3.329 & .378 & 4.047 & .000 \\
\hline & $\begin{array}{l}\text { Kebijakan } \\
\text { Dividen }\end{array}$ & 2.555 & 1.078 & .225 & 2.371 & .020 \\
\hline & Leverage & .759 & .660 & .110 & 1.150 & .254 \\
\hline & Profitabilitas & 14.357 & 3.156 & .429 & 4.549 & .000 \\
\hline
\end{tabular}

Perhitungan $t_{\text {tabel }}$ dalam penelitian ini adalah $(\mathrm{df}=75-4-1)=(\mathrm{df}=70)$ maka dapat dilihat nilai $\mathrm{t}_{\text {tabel }}$ pada tabel $\mathrm{t}$ sebesar 1.9944 atau 1.994.

Dari hasil uji t pada tabel 4.10 dapat dijelaskan pengaruh variabel independen secara parsial terhadap variabel dependen sebagai berikut:

1. Variabel pertumbuhan perusahaan terhadap nilai perusahaan diperoleh nilai signifikan $0.000<0.05$ dan $t_{\text {hitung }}$ sebesar $4.047>\mathrm{t}_{\text {tabel }}$ sebesar 1.994, jadi $\mathrm{t}_{\text {hitung }}>$ $\mathrm{t}_{\text {tabel }}(4.047>1.994)$, maka secara parsial variabel pertumbuhan perusahaan berpengaruh positif dan signifikan terhadap nilai perusahaan.

2. Variabel kebijakan dividen terhadap nilai perusahaan diperoleh nilai signifikan $0.020<0.05$ dan $t_{\text {hitung }}$ sebesar $2.371>$ $\mathrm{t}_{\text {tabel }}$ sebesar 1.994, jadi $\mathrm{t}_{\text {hitung }}>\mathrm{t}_{\text {tabel }}(2.371$ > 1.994), maka secara parsial variabel kebijaka dividen berpengaruh positif dan signifikan terhadap nilai perusahaan.

3. Variabel leverage terhadap nilai perusahaan diperoleh nilai signifikan $0.254>0.05$ dan $t_{\text {hitung }}$ sebesar $1.150<$ $\mathrm{t}_{\text {tabel }}$ sebesar 1.994, jadi $\mathrm{t}_{\text {hitung }}<\mathrm{t}_{\text {tabel }}(1.150$ < 1.994), maka secara parsial variabel leveragetidak berpengaruh dan tidak signifikan terhadap nilai perusahaan.

4. Variabel profitabilitas terhadap nilai perusahaan diperoleh nilai signifikan $0.000<0.05$ dan $t_{\text {hitung }}$ sebesar $4.549>$ $\mathrm{t}_{\text {tabel }}$ sebesar 1.994 , jadi $\mathrm{t}_{\text {hitung }}>\mathrm{t}_{\text {tabel }}(4.549$ > 1.994), maka secara parsial variabel profitabilitas berpengaruh positif dan signifikan terhadap nilai perusahaan.

\section{Uji Koefisien Secara Simultan (Uji F)} Tabel 10.Hasil Uji Koefisien Regresi Simultan (Uji F)

\begin{tabular}{|c|c|c|c|c|c|c|}
\hline \multicolumn{2}{|c|}{ Model } & $\begin{array}{r}\text { Sum of } \\
\text { Squares }\end{array}$ & Df & $\begin{array}{c}\text { Mean } \\
\text { Square }\end{array}$ & $F$ & Sig. \\
\hline \multirow[t]{3}{*}{1} & Regression & 267.090 & 4 & 66.772 & 12.611 & $.000^{\circ}$ \\
\hline & Residual & 370.637 & 70 & 5.295 & & \\
\hline & Total & 637.726 & 74 & & & \\
\hline
\end{tabular}

Berdasarkan hasil uji $\mathrm{F}$ pada tabel di atas, dapat dilihat $F_{\text {hitung }}$ sebesar 12.611 dengan tingkat signifikansi 0.000 . Nilai $\mathrm{F}_{\text {hitung }}$ akan dibandingkan dengan nilai $F_{\text {tabel }}$ pada tingkat kesalahan $\mathrm{a}=5 \%$ dengan derajat kebebasan df $1=\mathrm{k}-1$ dan df $2=\mathrm{n}-\mathrm{k}$. Jumlah sampel (n) sebanyak 75, dan jumlah variabel penelitian (k) berjumlah 4. Jadi $\mathrm{df}=(4-1)$; (75-4), sehingga $\mathrm{F}_{\text {tabel }}$ padatingkat kepercayaan 95\% $(\mathrm{a}=5 \%)$ adalah 2.73. Jadi $\mathrm{F}_{\text {hitung }}>\mathrm{Ft}_{\text {abel }}$ $(12.611>2.73)$ dan tingkat signifikansi sebesar 0.000 maka keputusan Ha diterima artinya pertumbuhan perusahaan, kebijakan deviden, leverage, dan profitabilitas secara simultan berpengaruh terhadap nilai perusahaan.

Uji Koefisien Determinasi ( $\mathbf{j i} \mathbf{R}^{\mathbf{2}}$ ) Tabel 11. Hasil Uji Koefisien Determinasi $\left(\mathbf{R}^{2}\right)$

\begin{tabular}{|l|r|r|r|r|r}
\hline Model & $\mathrm{R}$ & $\mathrm{R}$ Square & $\begin{array}{c}\text { Adjusted R } \\
\text { Square }\end{array}$ & $\begin{array}{c}\text { Std. Error of } \\
\text { the Estimate }\end{array}$ & $\begin{array}{c}\text { Durbin- } \\
\text { Watson }\end{array}$ \\
\hline 1 & $.647=$ & .419 & .386 & 2.30105 & 1.850 \\
\hline
\end{tabular}
(Sumber: Output SPSS Ver si 24)

Berdasarkan tabel 11 diatas nilai Adjusted $R$ Square, diperoleh nilai koefisien determinasi sebesar 0.386 atau $38.6 \%$ dari variabel pertumbuhan perusahaan, kebijakan dividen, leverage dan profitabilitas. Sedangkan sisanya $61.4 \%$ dijelaskan atau dipengaruhi oleh variabel-variabel lainnya (faktor atau rasio keuangan) lain yang tidak termasuk dalam model.

\section{Pembahasan Hasil Penelitian}

\section{Pengaruh Pertumbuhan Perusahaan terhadap Nilai Perusahaan}

Dari hasil pengujian secara parsial, variabel pertumbuhan perusahaan menunjukkan bahwa nilai $t_{\text {hitung }}$ sebesar 4.047>1.667 dengan nilai signifikansi $0.000<$ 0.05 , sehingga dapat dinyatakan bahwa pertumbuhan perusahaan berpengaruh signifikan terhadap nilai 
perusahaan.Perusahaan yang memiliki tingkat pertumbuhan yang tinggi setiap periodenya menunjukkan bahwa perusahaan mengalami perkembangan atau kemajuan. Dengan tingkat pertumbuhan yang semakin tinggi akan lebih mempermudah kegiatan operasional perusahaan seperti peningkatan penjualan, mempermudah pinjaman bank, dan meningkatnya kepercayaan investor terhadap suatu perusahaan karena citra perusahaan yang semakin meningkat seiring dengan pertumbuhan perusahaan. Hal ini tentunya akan meningkatkan harga saham dalam suatu perusahaan. Sehingga dengan meningkatknya harga saham maka nilai perusahaan juga akan meningkat. Penelitian ini sejalan dengan hasil penelitian yang dilakukan Chusnitah dan Retnani (2017), Putri (2015), Syardiana et al., (2015) dan Dewi, Yuniarta, dan Dewi (2014). Namun hasil penelitian ini tidak sejalan dengan penelitian yang dilakukan oleh Wibawa (2013).

\section{Pengaruh Kebijakan Dividen terhadap Nilai Perusahaan}

Dari hasil pengujian secara parsial, variabel kebijakan dividen menunjukkan bahwa nilai $\mathrm{t}_{\text {hitung }}$ sebesar $2.371>1.667$ dengan nilai signifikansi $0.020<0.05$, sehingga dapat dinyatakan bahwa kebijakan dividen berpengaruh signifikan terhadap nilai perusahaan. Jika perusahaan membagikan labanya kepada para pemegang saham dalam bentuk dividen maka hal tersebut akan meningkatkan harga saham. Karena dengan pembagian dividen maka akan memberikan sinyal positif kepada para pemegang saham. Dimana pemegang saham senang terhadap tingkat return atau pengembalian yang pasti dari investasinya. Hal ini tentunya akan memberikan dampak pada nilai suatu perusahaan. Penelitian ini sejalan dengan hasil penelitian yang dilakukan oleh Sudiartha (2016), Ngurah, Adi,dan Lestari (2016) dan Purnama (2016). Namun hasil penelitian ini tidak sejalan dengan penelitian yang dilakukan oleh Mardiyati (2012).

\section{Pengaruh Leverage terhadap Nilai Perusahaan}

Dari hasil pengujian secara parsial, variabel leverage menunjukkan bahwa nilai $t_{\text {hitung }}$ sebesar $1.150<1.667$ dengan nilai signifikansi $0.254>0.05$, sehingga dapat dinyatakan bahwa leverage tidak berpengaruh signifikan terhadap nilai perusahaan. Tinggi rendahnya tingkat leverage dalam suatu perusahaan tidak berpengaruh dikalangan para pemegang saham atau investor karena investor dalam menanamkan modalnya pada suatu perusahaan tidak melihat seberapa besar tingkat hutang yang dimiliki perusahaan. Dimana investor dalam menanamkan modalnya pada suatu perusahaan dengan melihat total ekuitas yang dimiliki perusahaan yang meningkat dari satu periode ke periode lainnya. Hal ini tentunya bisa memberikan kepercayaan kepada investor untuk menanamkan modalnya pada perusahaan tersebut. Penelitian ini sejalan dengan hasil penelitian yang dilakukan oleh Prasetyorini (2013) dan Putu Mikhy Novari (2016). Namun hasil penelitian ini tidak sejalan dengan penelitian yang dilakukan oleh Rudangga, I Gusti Ngurah Gede; Sudiarta (2016), Ernawati dan Widyawati (2015), Kuzey, Ali, dan Delen (2014), Mindra, Sukma dan Erawati (2014).

\section{Pengaruh Profitabilitas terhadap Nilai Perusahaan}

Dari hasil pengujian secara parsial, variabel leverage menunjukkan bahwa nilai $\mathrm{t}_{\text {hitung }}$ sebesar $1.150<1.667$ dengan nilai signifikansi $0.254>0.05$, sehingga dapat dinyatakan bahwa leverage tidak berpengaruh signifikan terhadap nilai perusahaan. Profitabilitas yang tinggi dalam suatu perusahaan akan memberi sinyal positif bagi investor bahwa perusahaan dalam kondisi yang menguntungkan atau dimana kemampuan perusahaan menghasilkan laba atas modal sendiri. Hal ini menjadi daya tarik investor untuk memiliki saham perusahaan tersebut, sehingga permintaan saham tinggi yang meningkat nilai perusahaan juga. Penelitian ini sejalan dengan hasil penelitian yang dilakukan oleh Dewi, Ayu Sri Mahatma; Wirajaya (2013), Kuzey, Ali, dan Delen (2014), Purnama (2016), Maryani (2016) dan Widiastari, Putu Ayu; Yasa (2018). Namun hasil penelitian ini tidak sejalan dengan penelitian yang dilakukan oleh M. T. Putri (2017).

Pengaruh Pertumbuhan Perusahaan, Kebijakan Dividen, Leverage dan Profitabilitas terhadap Nilai Perusahaan 
Dari hasil pengujian secara simultan, variabel penelitian memiliki $\mathrm{F}_{\text {hitung }}$ sebesar 12.611 lebih besar dari pada $F_{\text {tabel }} 2.73$ dengan derajat kebebasan df $1=4-1$ dan df $2=75-4$. dan tingkat signifikansi sebesar 0.000 maka hasil pengujian hipotesis diterima yang menunjukkan bahwa pertumbuhan perusahaan, kebijakan deviden, leverage, dan profitabilitas secara bersama-sama (simultan) berpengaruh terhadap nilai perusahaan. Hal ini berarti semakin tinggi pertumbuhan perusahaan, kebijakan deviden, leverage, dan profitabilitas secara bersama-sama (simultan) berpengaruh terhadap nilai perusahaan pada perusahaan manufaktur yang terdaftar di Bursa Efek Indonesia periode 2014-2017.

\section{Kesimpulan dan Saran Kesimpulan}

1.Berdasarkan hasil pengujian H1 menunjukkan bahwa Pertumbuhan Perusahaan berpengaruh signifikan terhadap Nilai Perusahaan pada Perusahaan Manufaktur yang terdaftar di Bursa Efek Indonesia periode 2014-2017.

2.Berdasarkan hasil pengujian $\mathrm{H} 2$ menunjukkan bahwa Kebijakan Dividen berpengaruh signifikan terhadap Nilai Perusahaan pada Perusahaan Manufaktur yang terdaftar di Bursa Efek Indonesia periode 2014-2017.

3.Berdasarkan hasil pengujian $\mathrm{H} 3$ menunjukkan bahwa Leverage tidak berpengaruh signifikan terhadap Nilai Perusahaan pada Perusahaan Manufaktur yang terdaftar di Bursa Efek Indonesia periode 2014-2017.

4.Berdasarkan hasil pengujian $\mathrm{H} 4$ menunjukkan bahwa Profitabilitas berpengaruh signifikan terhadap Nilai Perusahaan pada Perusahaan Manufaktur yang terdaftar di Bursa Efek Indonesia periode 2014-2017.

5.Berdasarkan hasil pengujian H5 menunjukkan bahwa secara simultan Pertumbuhan Perusahaan, Kebijakan Dividen, Leverage dan Profitabilitas berpengaruh signifikan terhadap Nilai Perusahaan pada Perusahaan Manufaktur yang terdaftar di Bursa Efek Indonesia periode 20142017.

\section{Saran}

1.Bagi Perusahaan
Bagi perusahaan, diharapkan lebih memperhatikan faktor-faktor apa saja yang dapat memengaruhi nilai suatu perusahaan dan lebih berhati-hati dalam mengambil kebijakan sehingga tidak menggurangi nilai perusahaan.

2.Bagi Investor

Sebaiknya investor mencari informasi yang cukup dan menganalisis terlebih dahulu keuangan perusahaan sebelum melakukan investasi. Seperti mencari informasi mengenai faktor-faktor apa saja yang dapat memengaruhi nilai perusahaan.

3.Bagi Peneliti Selanjutnya

Penelitian selanjutnya diharapkan dapat menggunakan sampel perusahaan selain perusahaan manufaktur dan memperpanjang periode penelitian serta dapat menambah atau mengganti variabel independen dalam penelitian ini dengan variabel lain yang dianggap dapat memberikan hasil lebih akurat serta memiliki pengaruh yang lebih dominan terhadap nilai perusahaan.

\section{Daftar Pustaka}

Chusnitah, N. M. \& Retnani, E. D. (2017).Pengaruh Struktur Modal, Pertumbuhan Perusahaan, Ukuran Perusahaan dan Profitabilitas Terhadap Nilai Perusahaan Nur Maghfirotu Chusnitah.Jurnal Ilmu Dan Riset Akuntansi Volume 6, Nomor 11, November 2017 Issn, 6(November), 121.

Dewi, Ayu Sri Mahatma; Wirajaya, A. (2013). Pengaruh Struktur Modal, Profitabilitas dan Ukuran Perusahaan Pada Nilai Perusahaan. E-Jurnal Akuntansi Universitas Udayana, 2, 358-372.

Dewi, P. Y. S., Yuniarta, G. A., \& Dewi, A. W. T. (2014). Pengaruh Struktur Modal, Pertumbuhan Perusahaan dan Profitabilitas Terhadap Nilai Perusahaan Pada Perusahaan Lq 45 Di Bei Periode 2008-2012. E-Journal S1 Akuntansi, 2(1), 1-10. 
Ernawati, D., \& Widyawati, D. (2015). Pengaruh Profitabilitas ,Leverage dan Ukuran Perusahaan Terhadap Nilai Perusahaan. Jurnal Ilmu Dan Riset Akuntansi Volume 4, Nomor 4, November 2015 Issn, 4(4), 117.

Ghozali, I. (2016). Aplikasi Analisis Multivariete Dengan Program Ibm Spss 23 (8th Ed.). Semarang: Badan Penerbit Univeristas Diponegoro.

Kuzey, C., Ali, U., \& Delen, D. (2014). Sistem Pendukung Keputusan Dampak Multinationality Pada Fi Nilai Perusahaan: Sebuah Analisis Komparatif Teknik Pembelajaran Mesin. Ilmu Manajemen Dan Sistem Informasi, 59, 127-142.

Https://Doi.Org/10.1016/J.Dss.2013.11.00 1

Mardiyati, U. G. N. A. R. P. (2012). Pengaruh Kebijakan Dividen, Kebijakan Hutang dan Profitabilitas Terhadap Nilai Perusahaan Manufaktur Yang Terdaftar Di Bursa Efek Indonesia (Bei) Periode 2005-2010. Riset Manajemen Sains Indonesia (Jrmsi), 3(1), 1-17. Retrieved From Dividend Policy, Debt Policy, Corporate Value, Insider Ownership

Maryani, L. (2016). Pengaruh Likuiditas, Profitabilitas, Kebijakan Dividen, Kebijakan Utang dan Kepemilikan Manajerial Terhadap Nilai Perusahaan Pada Perusahaan Manufaktur Yang Terdaftar Di Bursa Efek Indonesia Tahun 2010-2013. Umrah, 1-22.

Mindra, Sukma; Erawati, T. (2014). Pengaruh Earning Per Share (Eps), Ukuran Perusahaan, Profitabilitas, dan Leverage Terhadap Nilai Perusahaan (Studi Kasus Pada Perusahaan Manufaktur Yang Terdaftar Di Bursa Efek Indonesia Pada Tahun 2009-2011) Sukma. Akuntansi, 2(2).

Narbuko, Cholid; Achmadi, A (2016).Metodologi Penelitian. Jakarta: Pt. Bumi Aksara.

Ngurah, A. A., Adi, D., \& Lestari, P. V. (2016). Pengaruh Kebijakan Dividen, Likuiditas, Profitabilitas dan Ukuran Perusahaan
Terhadap Nilai Perusahaan, 5(7), 40444070.

Prasetyorini, B. F. (2013). Pengaruh Ukuran Perusahaan, Leverage, Price Earning Ratio dan Profitabilitas Terhadap Nilai Perusahaan. Ilmu Manajemen, 1, 183196.

Priyatno, D. (2017). Panduan Praktis Olah Data Menggunakan Spss (1st Ed.). Yogyakarta: Andi.

Purnama, H. (2016). Pengaruh Profitabilitas, Kebijakan Hutang, Kebijakan Deviden, dan Keputusan Investasi Terhadap Nilai Perusahaan (Studi Kasus Perusahaan Manufaktur Yang Go Publik Di Bursa Efek Indonesia) Periode 2010 - 2014. Akuntansi, 4(1), 11-21.

Putri, G. S. A. R. Z. E. (2015). Pengaruh Investment Opportunity Set, Struktur Modal , Pertumbuhan Perusahaan ,. Akuntabilitas, Viii(1), 39-46.

Putri, M. T. (2017). Pengaruh Profitabilitas Dan Keputusan Investasi Terhadap Nilai Perusahaan Pulp \& Paper Yang Terdaftar Di Bursa Efek Indonesia.Fisip, 4, 1-12.

Putu Mikhy Novari, P. V. L. (2016). Pengaruh Ukuran Perusahaan, Leverage, dan Profitabilitas Terhadap Nilai Perusahaan Pada Sektor Properti Dan Real Estate. E-Jurnal Manajemen Unud, 5(9), 5671-5694.

Rudangga, I Gusti Ngurah Gede; Sudiarta, G. M. (2016). Pengaruh Ukuran Perusahaan, Leverage, dan Profitabilitas Terhadap Nilai Perusahaan. E-Jurnal Manajemen Unud, 5(7), 4394-4422.

Sudiartha, N. K. R. P. I. G. M. (2016). Pengaruh Struktur Modal, Kebijakan Dividen, dan Ukuran Perusahaan Terhadap Nilai Perusahaan Pada Perusahaan Manufaktur.E-Jurnal Manajemen Unud, 5(3), 1572-1598.

Sugiyono. (2016). Metode Penelitian Kuantitatif, Kualitatif, Dan $R \& D$. Bandung: Alfabeta.

Wibawa, K. A. C. (2013). Pengaruh Pertumbuhan Perusahaan dan Struktur 
FE Universitas Maritim Raja Ali Haji

Kepemilikan Terhadap Struktur Modal Dan Nilai Perusahaan Pada Perusahaan Properti Di Bei.Forum Manajemen, 11, 87-105.

Widiastari, Putu Ayu; Yasa, G. W. (2018).Pengaruh Profitabilitas, Free Cash Flow, dan Ukuran Perusahaan Pada Nilai Perusahaan.E-Jurnal Akuntansi Universitas Udayana, 23, 957-981. 